\title{
HISTOPATHOLOGICAL STUDY OF OVARIAN TUMORS IN PAEDIATRIC AGE GROUP.
}

M. Ramani ${ }^{1}$, O. H. Radhika Krishna ${ }^{2}$, Geetha ${ }^{3}$, Ramesh Reddy ${ }^{4}$, P. Sreenivasa Reddy ${ }^{5}$, N. Amulya ${ }^{6}$, Puja Deshmukh7, Snehal ${ }^{8}$.

1. Professor, Department of Pathology, Niloufer Hospital, Hyderabad.

2. Assistant Professor, Department of Pathology, Niloufer Hospital, Hyderabad

3. Assistant Professor, Department of Pathology, Niloufer Hospital, Hyderabad

4. Professor \& H.O.D, Department of Paediatric Surgery, Niloufer Hospital, Hyderabad.

5. Professor \& H.O.D, Department of Paediatric Surgery, Niloufer Hospital, Hyderabad.

6. III Year, Undergraduate, Osmania Medical College, Hyderabad.

7. Post Graduate, Department of Pathology, Niloufer Hospital,

8. Post Graduate, Department of Pathology, Niloufer Hospital,

\section{CORRESPONDING AUTHOR:}

Dr. M. Ramani,

Professor, Department of Pathology,

Niloufer Hospital, Hyderabad, Andhra Pradesh.

E-mail: drmramani@sify.com

\section{HOW TO CITE THIS ARTICLE:}

M. Ramani, O. H. Radhika Krishna, Geetha, Ramesh Reddy, P. Sreenivasa Reddy, N. Amulya, Puja Deshmukh, Snehal. "Histopathological Study of Ovarian Tumours in Paediatric Age Group". Journal of Evolution of Medical and Dental Sciences 2013; Vol2, Issue 24, June 17; Page: 4264-4276.

ABSTRACT: Ovarian tumors are rare in children and constitute $1 \%$ of all childhood malignancies and $8 \%$ of abdominal tumors. Large cysts and those complicated by torsion make their presence clear by their symptomatology. However, ovarian pathology is still mostly discovered at laparotomy for presumptive appendicitis. Accurate diagnosis of these tumors at such a young age is a great challenge to surgeons and pathologists. This article reviews the clinical presentation, radiological imaging, gross and histopathological findings at the Pathology Department of a Paediatric Referral centre in Hyderabad

KEY WORDS: Ovarian tumors, pediatric age group, neoplastic, non-neoplastic lesions, germ cell tumors, surface-epithelial tumors, sex cord tumors.

INTRODUCTION: Ovarian tumors are rare in children and constitute $1 \%$ of all childhood malignancies and $8 \%$ of abdominal tumors. Moreover, 10 to $30 \%$ of ovarian neoplasm operated during childhood or adolescent girls are malignant. It is well-known that germ-cell tumors are the commonest ovarian neoplasm in the first two decades of life constituting approximately two-thirds of all ovarian tumors.

Malignant germ cell tumors constitute one-third of germ cell origin tumors and two-thirds of all ovarian malignancy in this age-group (1) Norris and Jensen found that $<1 \%$ of epithelial carcinoma occurs below 20 years of age (2). Sex cord stromal tumors are rare tumors accounting for $5 \%-8 \%$ of all ovarian malignancies (3). Granulosa cell tumors are found in pre pubertal girls in 
five percent of cases. Ovarian pathology is mostly discovered at laparotomy for presumptive appendicitis and surprises the surgeons; detection of these tumors at such a young age is a great challenge to surgeons and pathologists.

AIM: To analyze - Various ovarian lesions in paediatric age group, to categorize the histopathological entities and to correlate with literature

MATERIALS AND METHODS: Clinical cases diagnosed as ovarian lesions over a 5-year period in paediatric age group (Jan 2005 to Dec 2010) were included in the study. The clinical, radiological, gross and microscopic findings were analyzed. Lesions were classified and immunohistochemistry done wherever necessary.

RESULTS: 35 cases of ovarian tumor specimens of girls upto 18 years of age over a period of five years examined.

( Table 1 )shows 35 specimens of ovarian tumors in girls up to 18 years of age during the five years period and respective ages at presentation. Majority of cases were in the age group 612years -13 cases correction gap between 12 and years. Of the 35 cases, 18 cases were neoplastic (51.55\%) and 17 (48.54\%) were Nonneoplastic - (Figure: 1 )

Of the 18 cases of neoplastic tumors $2(5.7 \%)$ were of surface epithelial origin (1case of serous cystadenocarcinoma and 1 case of mucinous adenocarcinoma). Majority of the tumors- 15 $(42.9 \%)$ were of germ cell origin and 8 were teratomas, 5 endodermal sinus tumors, 2 dysgerminomas-(Table 5). 1 (2.9\%) was a Sex cord tumor-juvenile granulosa cell tumor).

Majority of the non-neoplastic lesions were simple cysts - 8 cases $(22.9 \%)$ followed by follicular cysts -4 cases $(11.42 \%)$, massive edema - 3 cases $(8.75 \%)$, endometriosis - 1 case $(2.85 \%)$, corpus luteal cyst with extensive hemorrhage - 1 case $(2.85 \%)$ - (Table4).It was observed that the ovarian tumors in paediatric age group were common below 10 years of age-(Table 7).Neoplastic lesions were more common between 6-10 years. Non-neoplastic lesions were common between 3days to 1year- (Figure: 2)

Out of 35 cases, major clinical feature in 21 cases was acute abdominal pain. 09 cases presented with mass abdomen and vague abdominal pain, 06 cases with irregular menstrual cycles, 05 cases with mass abdomen, 02 cases withascites, 02 cases with precocious puberty and 01 case with vaginal bleeding- (Table 2 )

The gross findings focused on two parameters - nature and size of mass, nature - whether unilocular/multilocular and solid or cystic or solid-cystic/variegated. Based on size: tumors were divided into four groups i.e. less than $5 \mathrm{~cm}, 6-10 \mathrm{~cm}, 11-15 \mathrm{~cm}$ and more than $15 \mathrm{~cm}$. Of the 35 cases, only 03 cases were above $15 \mathrm{~cm}$ size. Majority -15 ranged from $6-10 \mathrm{~cm}$. On cut section 17 cases were found to be cystic, 18 showed solid-cystic or variegated appearance. Solid or solid-cystic ovarian masses are generally indicative of malignancy.

Gross appearance of tumors was considered important in our study to correlate with histopathological type. Most of neoplastic lesions were simple cysts (8 cases). Radiological findings showed that majority of cases -19 were cystic, the rest were solid and cystic in 12 cases and solid in 04 cases.( Table 3 ) 
Among non-neoplastic lesions: (Figure - 3), Simple cyst: 8/35 cases - lined by flattened epithelium.-(Figure: 5), Follicular cyst:2/35 cases- thin walled lined by an inner layer of granulosa cells and an outer layer of theca cells- ( Figure: 6 )

Massive edema:3/35 cases- ovaries enlarged, cut surface densely sclerotic and pale, spindle cells in thick fibrotic cortex- (Figure:7), Endometriosis: 1/35 cases -lobular with solid and cystic areas , presence of endometrial glands and stroma

Corpus luteal cyst with extensive hemorrhage: 1/35 cases: yellow cream colored luteinized granulosa cells.

\section{Among neoplastic lesions :( Figure -4),}

I) Surface Epithelial Cells: 2/35 cases, Serous cystadenoma- unilocular, thin-walled cysts ,lined by ciliated columnar cells- (Figure: 8) and Mucinous cystadenoma-multilocular, thin walled cysts , lining of tall columnar epithelium with papillary growth-(Figure :9).

II) Germ cell tumors:Teratoma-8/35 cases-unilocular cysts , cheesy sebaceous material, cyst wall lined by stratified squamous epithelium with underlying sebaceous glands, hair shafts and structures from other germ layers such as cartilage, adipose tissue, nerve bundles, and glands(Figure :10) .Endodermal sinus tumors-5/35 cases - well encapsulated, solid, areas of hemorrhage and necrosis. Cut surface slippery and mucoid- (Figure: 11) "Schiller-Duval body". intra and extracellular hyaline droplets staining positive for alpha-fetoprotein- (Figure: 12)Dysgerminomas2/35 cases- solid tumors, yellow-white to grey tan with areas of hemorrhage and necrosis, cells dispersed in sheets and cords separated by scant fibrous stroma. On immunohistochemistry, C-kit positive- (Figure: 13)

III) Sex cord-stromal tumors: Juvenile Granulosa-Theca cell tumor-1/35 cases- solid encapsulated cystic areas with -“Call-Exner bodies" Strong immune histochemical positivity with antibody to inhibin - (Figure: 14)

DISCUSSION: Ovarian tumors in the paediatric age group are not infrequent (4), Oumachigui et al, 1991 found the incidence to be six per cent of all ovarian tumors. Bren and Maxon reported that $35 \%$ of all ovarian neoplasms in childhood and adolescent were malignant (5). But we found incidence of neoplastic ovarian tumors in this age group as 51.55\%. Ehren et al. reported that 60 $85 \%$ of ovarian neoplasm of Paediatric age group were of germ-cell origin (6). In our study, 15 cases were of germ cell origin (42.9\%).

We found that in our series, incidence of germ-cell tumors was higher. On the contrary, there is increased incidence of surface epithelial tumors (58/151 cases-38.4\%) in a study conducted by Nirmal et al (7) Comparative study between present study and Nirmal et al., Shawis et al, Abdulla et al (8) studies is shown in the Table [6] Karaman A et al. in a review article commented that superficial epithelial ovarian tumors are unusual in adolescent girls and extremely rare before menarche. (10)

CONCLUSION: Though ovarian lesions are rare in children, we have found 35 cases over a period of 5 years. They were incidentally discovered due to symptoms such as acute pain abdomen and physical examination and imaging were usually inconclusive. Hence we infer that histopathological examination has a major role to play in the final diagnosis and prognosis of pediatric ovarian 
lesions particularly in cases where lesions are malignant. It is important that ovarian masses need to be included in the differential diagnosis of girls presenting with abdominal pain, mass or features of precocious puberty.

\section{REFERENCES:}

1. Scully RE et al. Germ cell tumors: Tumors of the ovary, maldeveloped gonads, fallopian tube and broad ligament, Washington DC: Armed Forces Institute of Pathology; 1998-239-66.

2 Norris HJ et al. Relative frequency of ovarian neoplasm in children and adolescents, Cancer, 1972; 30:713-9.

3. Berek JS, Hacker NF, Ovary and Fallopian tubes, In: Haskell CM, editor, Cancer treatment 4th edition, Philadelphia: WB Saunders; 1995:628-61.

4. Oumachigui, Narasimhan KL, Reddy KS. et al. A clinico-pathologic study of ovarian tumors in children, J Obstet Gynecol 1991; 140: 441-445.

5. Bren JL, Maxon WS, Ovarian tumors in children and adolescents, Clinical Obstet Gynecol 1977; 20:607-23.

6. Ehren IM, Mahour GH, Issacs H Jr, Benign and malignant ovarian tumors in children and adolescents: A review of 63 cases, Am J Surg 1984; 147:339-44.

$7 \quad$ Nirmal Kumar et al ; Ovarian tumors in Paediatric age group -A Clinico pathological study of 10 years' cases in West Bengal India , Indian Journal of Medicine and Paediatric Oncology ; 2010; 31( 2 ): 54-57.

8. Mohammed Abdullahi et al. A histopathological study of ovarian neoplasms in children in a tertiary hospital of Nigeria -African Journal of Paediatric Surgery, 2010, May -Aug 7(2): 7577.

9. Karaman A et al, A huge ovarian Mucinous cystadenoma in 14-year old pre menarchal girl: Review on ovarian mucinous tumor in pre menarchal girls, J Pediat Adolesc Gynecol 2008:21:41-4.

TABLE 1-AGE PRESENTATION

\begin{tabular}{|l|l|}
\hline AGE GROUP & NO.OF CASES \\
\hline 3 days -1 yr & 08 \\
\hline 1 yr -5 yrs & 04 \\
\hline 6 yrs -10 yrs & 13 \\
\hline 11 yrs -15 yrs & 07 \\
\hline $16 y r s-18$ yrs & 03 \\
\hline
\end{tabular}




\section{ORIGINAL ARTICLE}

TABLE 2-CLINICAL PRESENTATION:

\begin{tabular}{|l|l|}
\hline CLINICAL FEATURES & NO. OF CASES \\
\hline Acute pain abdomen & 21 \\
\hline Mass abdomen + Pain & 09 \\
\hline Irregular menses & 06 \\
\hline Mass abdomen & 05 \\
\hline Ascites & 02 \\
\hline Precocious puberty & 02 \\
\hline Vaginal bleeding & 01 \\
\hline
\end{tabular}

TABLE 3-RADIOLOGICAL APPEARANCE:

\begin{tabular}{|l|l|}
\hline FINDINGS & NO.OF CASES \\
\hline CYSTIC & 19 \\
\hline SOLID & 04 \\
\hline CYSTIC AND SOLID & 12 \\
\hline
\end{tabular}

HISTOPATHOLOGY:

TABLE 4-NON-NEOPLASTIC LESIONS- 17 / 35 (48.45\%)

\begin{tabular}{|c|c|c|}
\hline LESIONS & $\begin{array}{l}\text { NO. OF } \\
\text { CASES }\end{array}$ & PERCENTAGE \\
\hline Simple cysts & 08 & $22.9 \%$ \\
\hline Follicular cysts & 04 & $11.42 \%$ \\
\hline Massive edema & 03 & $8.75 \%$ \\
\hline Endometriosis & 01 & $2.85 \%$ \\
\hline $\begin{array}{l}\text { Corpus luteal } \\
\text { cyst with } \\
\text { extensive } \\
\text { hemorrhage }\end{array}$ & 01 & $2.85 \%$ \\
\hline
\end{tabular}




\section{ORIGINAL ARTICLE}

TABLE 5-NEOPLASTIC LESIONS - 18 / 35 (51.55 \%)

\begin{tabular}{|l|l|l|}
\hline LESIONS & NO.OF CASES & PERCENTAGE \\
\hline I) SURFACE EPITHELIAL TUMORS & $02 / 35$ & $5.7 \%$ \\
\hline Serous Cystadenoma & 01 & \\
\hline Mucinous Cystadenoma & 01 & \\
\hline II) GERM CELL TUMORS & $15 / 35$ & $42.9 \%$ \\
\hline Teratoma & 08 & \\
\hline Endodermal Sinus Tumour & 05 & \\
\hline Dysgerminoma & 02 & $2.9 \%$ \\
\hline III)SEX CORD STROMAL TUMORS & $01 / 35$ & \\
\hline Juvenile granulosa cell tumour & 01 & \\
\hline
\end{tabular}

TABLE 6-COMPARATIVE STUDIES

\begin{tabular}{|l|l|l|l|l|}
\hline STUDIES & $\begin{array}{l}\text { NIRMAL } \\
\text { et al. }\end{array}$ & $\begin{array}{l}\text { SHAWIS } \\
\text { et al. }\end{array}$ & $\begin{array}{l}\text { ABDHULLAHI } \\
\text { et al. }\end{array}$ & $\begin{array}{l}\text { PRESENT } \\
\text { STUDY }\end{array}$ \\
\hline No.of cases & 151 & 71 & 48 & 35 \\
\hline Age range & Upto 20yrs & 2 days-13 yrs & Upto 15yrs & 3 days-18yrs \\
\hline Study Period & $10 y$ rs & 32 yrs & $25 y$ s & 5 yrs \\
\hline $\begin{array}{l}\text { Non- neoplastic } \\
\text { lesions }\end{array}$ & $\begin{array}{l}24 / 15 \\
15.9 \%\end{array}$ & $\begin{array}{l}23 / 71 \\
32.4 \%\end{array}$ & - & $\begin{array}{l}17 / 35 \\
48.5 \%\end{array}$ \\
\hline $\begin{array}{l}\text { Neoplastic } \\
\text { lesions }\end{array}$ & $\begin{array}{l}127 / 151 \\
84.1 \%\end{array}$ & $\begin{array}{l}48 / 71 \\
67.6 \%\end{array}$ & 48 & $\begin{array}{l}18 / 35 \\
51.5 \%\end{array}$ \\
\hline $\begin{array}{l}\text { Most common } \\
\text { lesions }\end{array}$ & $\begin{array}{l}\text { Surface } \\
\text { Epithelial } \\
\text { tumors }\end{array}$ & $\begin{array}{l}\text { Germ cell } \\
\text { tumors }\end{array}$ & $\begin{array}{l}\text { Germ cell } \\
\text { tumors }\end{array}$ & $\begin{array}{l}\text { Germ } \\
\text { tumors }\end{array}$ \\
& $\begin{array}{l}58 / 151 \\
38.4 \%\end{array}$ & $\begin{array}{l}38 / 71 \\
53.5 \%\end{array}$ & $\begin{array}{l}28 / 42 \\
58 \%\end{array}$ & $\begin{array}{l}15 / 35 \\
42.9 \%\end{array}$ \\
\hline
\end{tabular}




\section{ORIGINAL ARTICLE}

TABLE 7-OVARIAN MASS VS AGE:

\begin{tabular}{|l|l|l|l|l|}
\hline \multirow{2}{*}{ STUDIES } & \multicolumn{2}{|c|}{ NON-NEOPLASTIC } & \multicolumn{2}{l|}{ NEOPLASTIC } \\
\cline { 2 - 5 } & $<10 \mathrm{yrs}$ & $>10 \mathrm{yrs}$ & $<10 \mathrm{yrs}$ & $>10 \mathrm{yrs}$ \\
\hline \multirow{2}{*}{ NIRMAL et al. } & $1 / 151$ & $23 / 151$ & $8 / 151$ & $132 / 151$ \\
& $0.66 \%$ & $15.2 \%$ & $5.2 \%$ & $87.4 \%$ \\
\hline & & & & \\
\hline & $12 / 35$ & $5 / 35$ & $13 / 35$ & $5 / 35$ \\
PRESENT STUDY & $34.3 \%$ & $14.3 \%$ & $37.14 \%$ & $14.3 \%$ \\
\hline
\end{tabular}

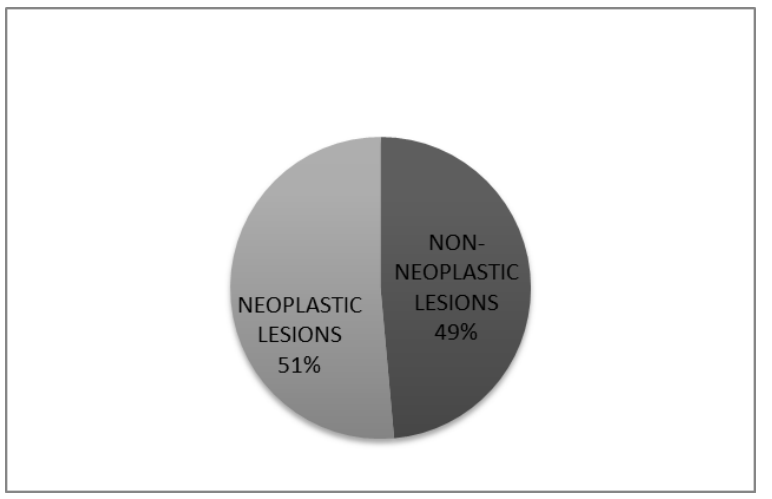

FIGURE 1: NEOPLASTIC VS NON-NEOPLASTIC LESIONS

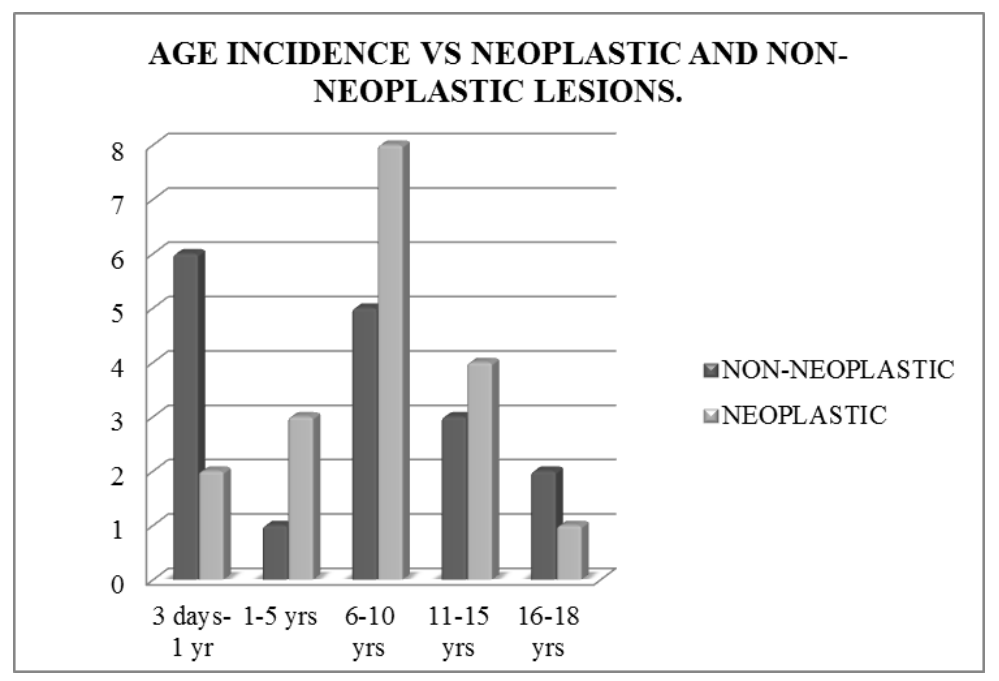

Figure 2: Age Incidence Vs Neoplastic and Non-Neoplastic Lesions. 


\section{ORIGINAL ARTICLE}

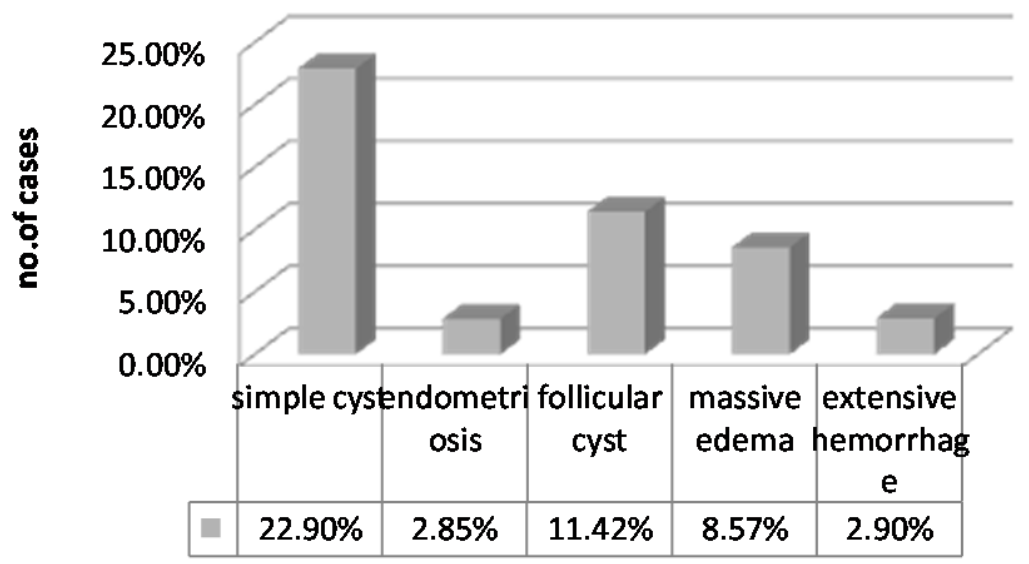

Figure 3: Non- neoplastic lesions.

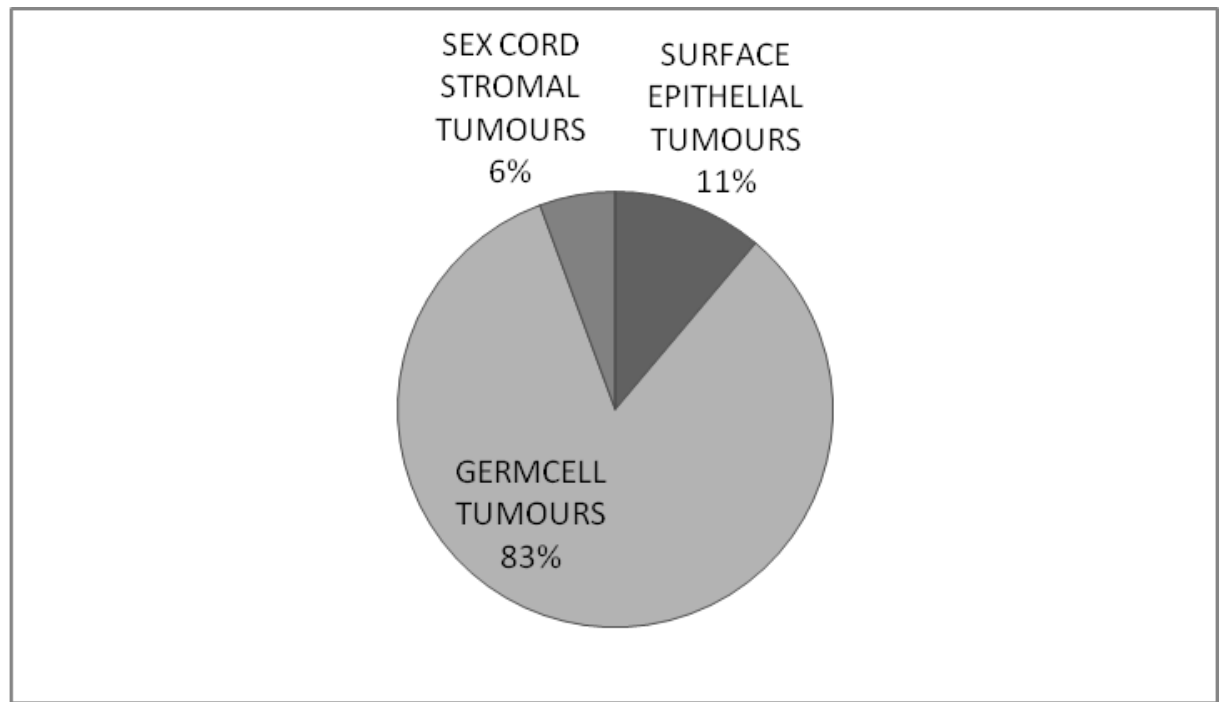

FIGURE 4: NEOPLASTIC LESIONS. 


\section{ORIGINAL ARTICLE}



FIGURE 5:(a) Ultrasonography of abdomen showing ovarian cyst (b) Gross of simple ovarian cyst (c) photomicrograph showing simple ovarian cyst.(H \&E 10x).



(b)

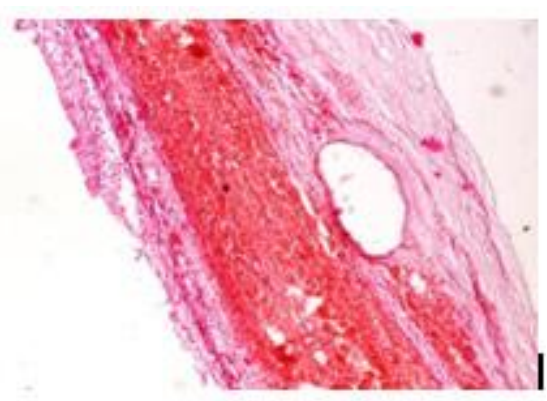

(c)
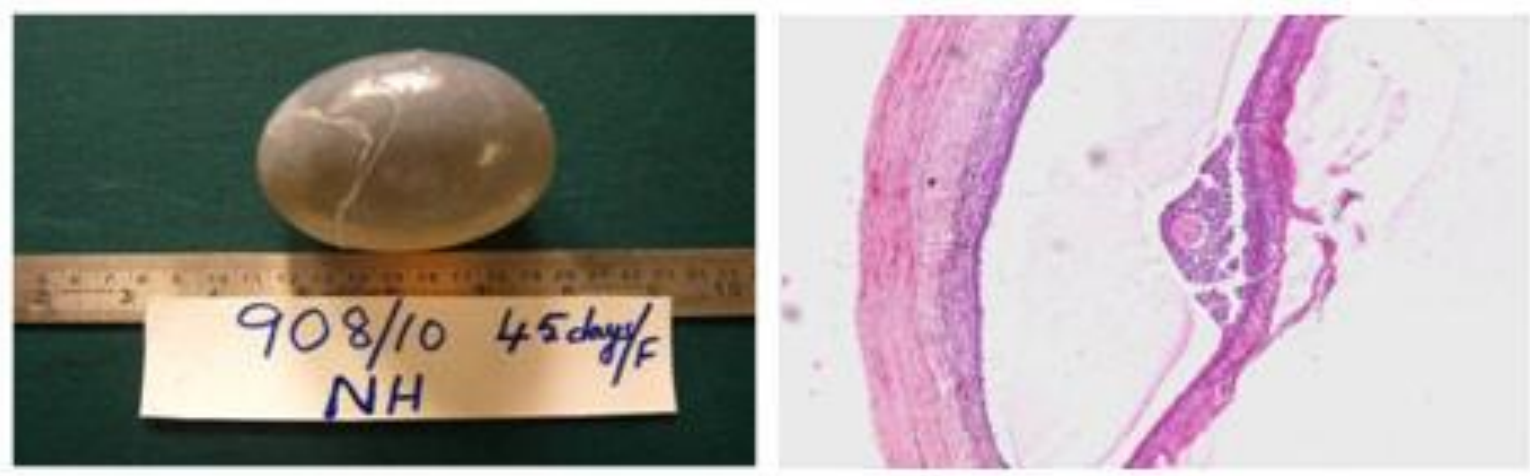

FIGURE 6: (a) Gross specimen of Follicular cyst. (b)Photomicrograph showing follicular cyst in the ovary.(H\&E,10X) 


\section{ORIGINAL ARTICLE}


FIGURE 7: (a) Gross specimen of serous cystadenoma. (b) Photomicrograph showing cyst wall lined by columnar epithelium.(H\&E 40X).


FIGURE 8: (a)Gross specimen of ovary with massive oedema (b) Photomicrograph showing massive oedema of ovary.(H\&E 40x)

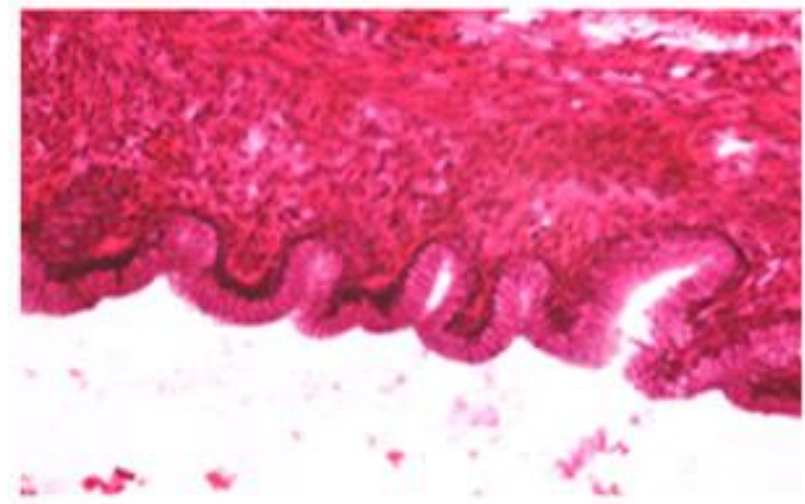

FIGURE 9: Photomicrograph of mucinous cystadenoma showing lining of tall columnar epithelium with papillary growths. (H\&E, 10X) 


\section{ORIGINAL ARTICLE}
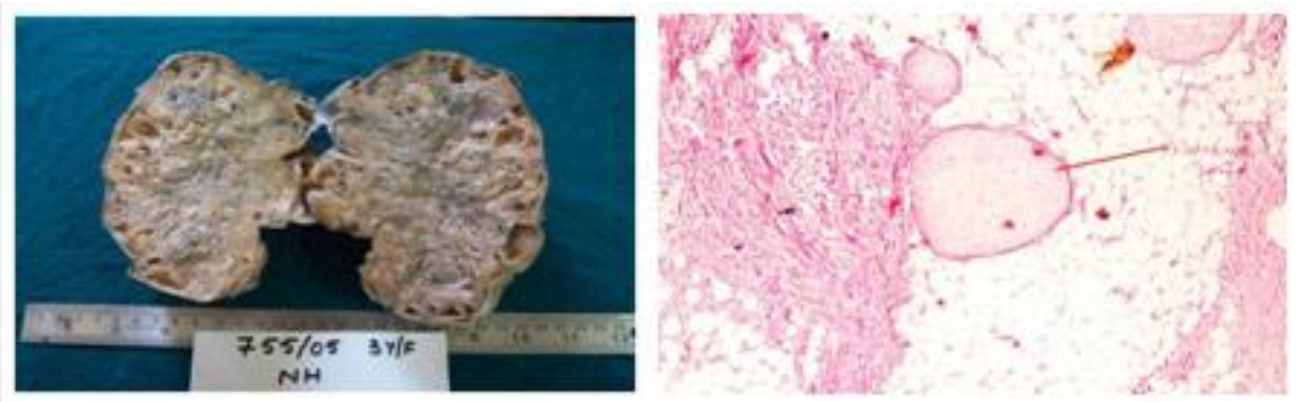

FIGURE10: (a) Gross specimen of teratoma showing heterogenous appearance.(b)Photomicrograph of teratoma showing cartilage and adipose tissue.(H\&E 10X)

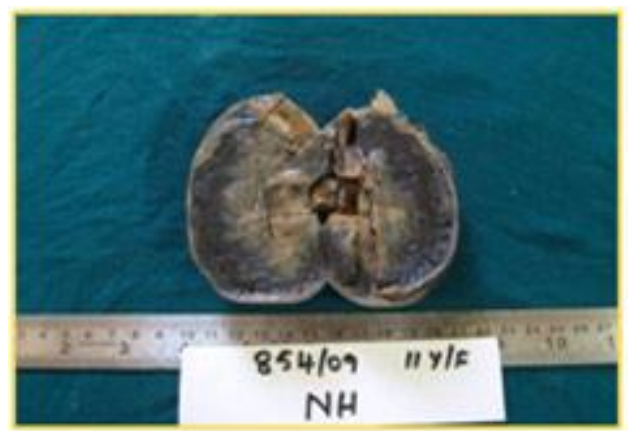

(a)

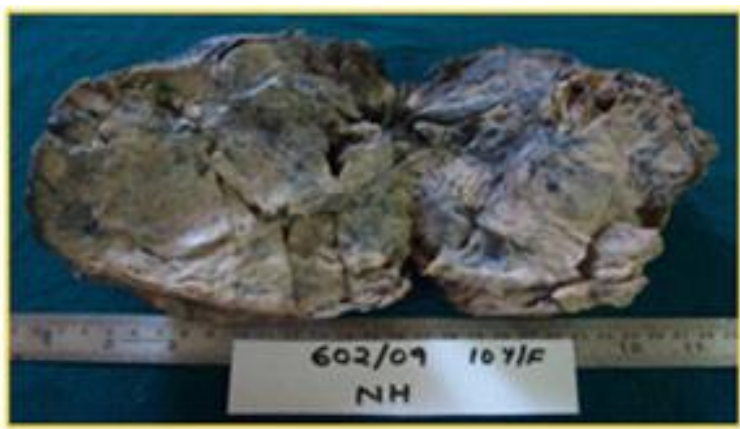

(b)

FIGURE 11: (a) \&(b) Cut sections of Endodermal sinus tumors of ovary showing necrosis.

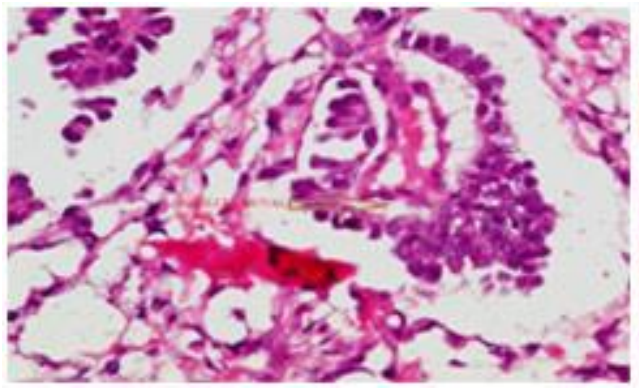

(a)

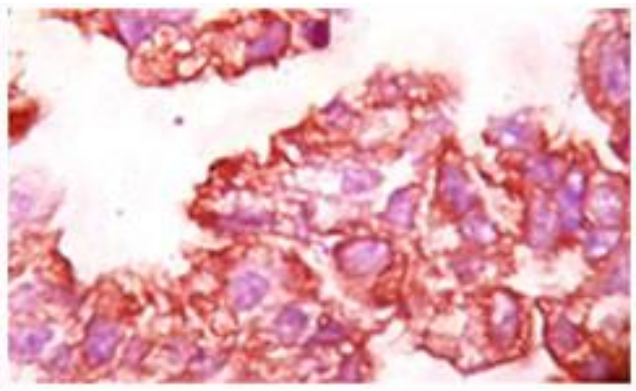

(b)

FIGURE 12 : (a)Photomicrograph showing Schiller Duval bodies. (H\&E,40X) characteristic of endodermal sinus tumor (b) Immunohistochemistry for endodermal sinus tumor showing positivity for Alpha feto-protein.(40X) 


\section{ORIGINAL ARTICLE}

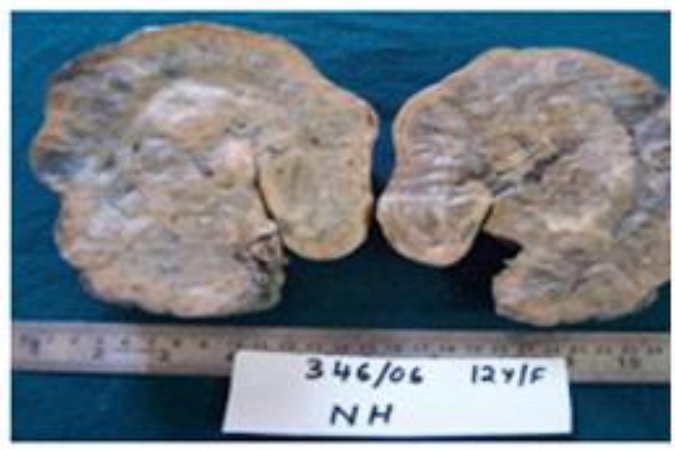

(a)

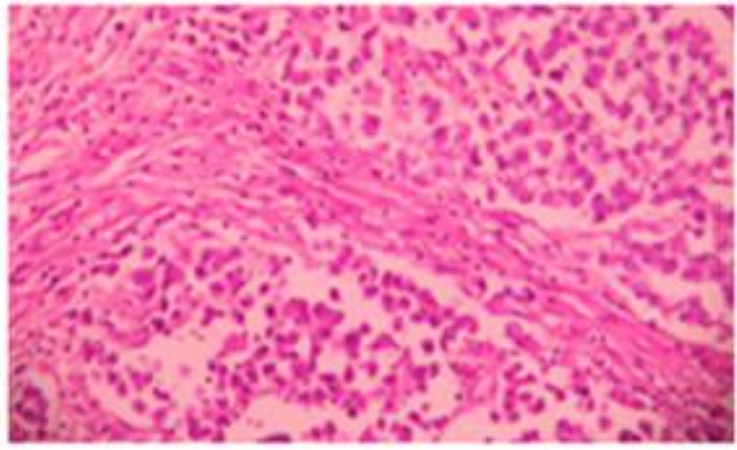

(b)

FIGURE 13: (a) Cut section of dysgerminoma showing solid,grey tan areas, hemorrhage, and necrosis.(b)Photomicrograph showing dysgerminoma cells dispersed in sheets or cords separated by scant fibrous stroma.(H\&E 10X).

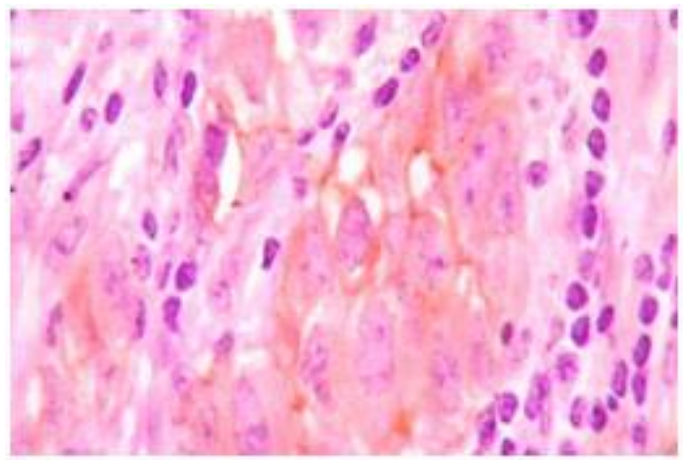

(c) Immunohistochemistry showing positivity for C-kit.
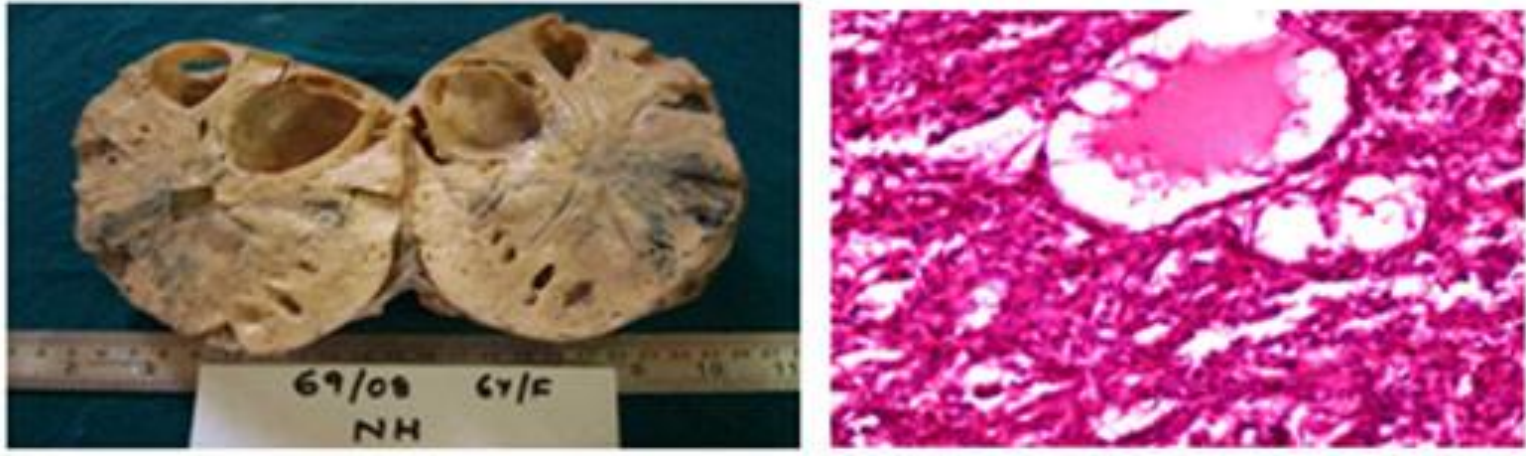

(a) (b)

FIGURE 14 :(a) Cut section of Juvenile granulosa theca cell tumor showing cystic areas.(b) Microscopy showing "Call-Exner bodies" (H\&E 40X). 


\section{ORIGINAL ARTICLE}

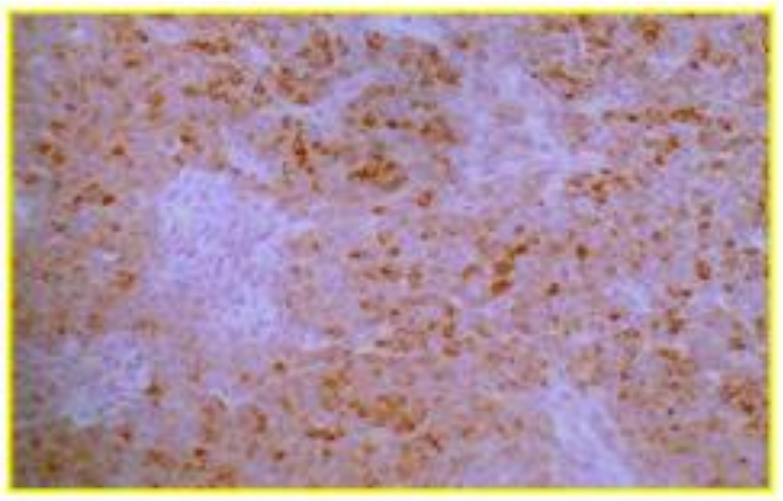

c) Strong immunohistochemical positivity with an antibody to inhibin. 